\title{
Organização judiciária
}

\section{A especialização das varas criminais e a investidura dos promotores públicos}

Waldemar Ferreira

O Govêrno do Estado, pelo decr. n..$^{\circ} 6.253$, de 29 de dezembro de 1933, estabeleceu novas regras para o ingresso dos promotores públicos da Capital na magistratura, autorizando-os a concorrerem com os magistrados de carreira no provimento de varas criminais da Capital. Essa autorização não exige concurso, nem tirocinio na carreira, e, sôbre os concurrentes, deve manifestar-se somente a Câmara Criminal do Tribunal de Justiça composta apenas de tres ministros.

Diante disso, pergunta-se:

I. Em face da Constituição Ėstadual não revogada expressamente nessa parte e das leis orgânicas da magistratura, que exige o concurso para a primeira investidura na magistratura, é legal êsse decreto? 
II. Prescrevendo o Codigo dos Interventores que nenhuma nomeação se fará sem audiencia e aprovação do mais alto Tribunal do Estado, é legal a investidura dos promotores com a aprovação somente da Câmara Criminal, por maioria de votos, quando o Tribunal paulista tem 18 ministros?

III. Estabelecendo que só os promotores públicos da Capital podem concorrer, criou com isso o decreto um privilégio a favor de uma parte da classe: é legal o decreto que assim estabeleceu?

IV Ingressando na magistratura criminal por êsse decreto ficam os promotores inibidos de passarem por meio de remoção ás varas civeis?

Instituindo o Govêrno Provisorio, instaurado pelo movimento revolucionario vitorioso dias antes, o decr. n..$^{\circ} 19.398$, de 11 de novembro de 1930, art. 4, lançou o principio de continuarem em vigor as constituições federal e estaduais, as demais leis e decretos estaduais, assim como as posturas $e$ outros atos municipais, todos, porém, inclusivé as proprias constituições, sujeitos ás modificações e restrições estabelecidas por aquele decreto e por outros decretos ou atos ulteriores do Govêrno Provisorio ou de seus delegados na esfera de atribuições de cada um. Não ficaram as constituições, leis, decretos, posturas e atos imutaveis nos pontos não expressamente por aquele decreto derrogados. Reservou-se o Govêrno Provisorio, por si ou por seus delegados, na esfera das atribuições de cada um, a faculdade de modifica-los por decretos ou atos posteriores.

Vedou, tempos depois, o decr. n. ${ }^{\circ} 20.348$, de 29 de agosto de 1931, art. 11, d), aos govêrnos estaduais, bem assim aos municipais, sem prévia e expressa autorização do Goviêrno Provisorio e mediante parecer anterior do Concelho Consultivo, "modificar ou derrogar a respectiva constituição ou lei orgânica, e, em geral, praticar todo e qualquer ato excedente da competencia do respectivo legislativo ordinario, ressalvado o disposto nos artigos antecedentes". 
Como, em tais condições, ficou a organização judiciaria 'dos Estados?Ficaram estes com a faculdade de modifica-la, de acôrdo com as novas diretrizes, rompendo com as prescrições por ventura consignadas nas suas respectivas constituições e leis orgânicas da sua magistratura?

Se, de um lado, estabeleceu o decr. n..$^{\circ} 19.398$, de 11 de novembro de 1930 , art. 3, a norma geral de o poder judiciario, tanto o federal, quanto o dos Estados, o do territorio do Acre e o do Distrito Federal, continuar a ser exercido na conformidade das leis em vigor, com as modificações que viessem a ser adotadas de acôrdo com aquele mesmo decreto e com as restrições dele decorrentes; de outro o decr. n. ${ }^{\circ} 20.348$, de 29 de agosto de 1931, art. 27, preceituou que, logo que reorganizassem os seus tribunais judiciarios, os Estados adotariam a regra de fazerem-se todas as nomeações ou promoções para cargos da magistratura mediante expressa aprovação do mais alto tribunal judiciario do Estado, em escrutinio secreto, salvo quando realizados por indicação do mesmo tribunal, em lista de tres nomes, no maximo.

Quando a revolução de 1930 se tornou vitoriosa, vigorava no Estado de São Paulo a Constituição Politica de 8 de julho de 1929, que exarara, no seu art. 55, o principio basilar de dever ser o primeiro provimento dos cargos de magistratura "precedido de concurso".

Mandou o decr. n. 4.773 , de 14 de novembro de 1930 , reorganizar a magistratura do Estado, permitindo a aposentadoria, a juizo do Govêrno, de seus membros e a demissão daqueles contra os quais se apurassem faltas graves, permitindo-lhe, ademais, nomeasse livremente para os cargos de juizes e de ministros do Tribunal de Justiça, que vagassem, doutores ou bachareis em Direito que escolhesse, na magistratura ou fóra dela.

Mercê desse dispositivo, advogados, delegados de policia e promotores públicos foram, independentemente de concurso, nomeados para a magistratura, tanto de primeira, quanto de segunda instancia. 
Reorganizando o Ministerio Publico do Estado, o decr. n. ${ }^{\circ} 5.179$, de 29 de agosto de 1931, art. 16, concedeu preferencia na classificação e na nomeação, nos concursos para o cargo de juiz substituto, em igualdade de condições, ao: funcionarios do Ministerio Publico; e o art. 17 permitiu aos promotores públicos da Capital concorrerem com os juizes de direito para o provimento dos cargos de juizes de direito das comarcas de primeira, segunda e terceira entrancias. As nomeações seriam feitas de acôrdo com lista apresentada pela Primeira Câmara do Tribunal de Justiça, com a presença do presidente do Tribunal e procurador geral do Estado, ambos com direito a voto, e na qual, por merecimento, seriam classificados os promotores inscritos. Apresentar-se-ia essa lista ao Govêrno juntamente com a organizada para promoção e remoção de juizes, podendo recair a nomeação em qualquer dos indicados nas duas listas.

Deu, logo depois, o decr. n. ${ }^{\circ} 5.215$, de 1 de outubro de 1931 outra redação ao art. 17, acima transcrito quasi textualmente. Ficou sendo êste o seu novo texto:

“Art. 17. Os promotores públicos da Capital, com quatro anos de efetivo exercicio na Comarca, podem ser nomeados juizes de direito das comarcas de primeira, segunda e terceira entrancias.

"Paragr. 1. A Primeira Câmara do Tribunal dé Justiça classificará, por merecimento, os que se inscreverem, podendo eliminar todos ou alguns dos candidatos, se julgar inconveniente a nomeação. Podem intervir na dcliberação. o presidente do Tribunal e o procurador geral do Estado.

"Paragr. 2. A lista dos classificados será apresentada ao Govêrno juntamente com a organizada pelas Câmaras Reunidas para promoção e remoção de juizes, podendo recair a nomeação em qualquer dos indicados nas duas listas"

Ficou, desde então, permitido o ingresso na magistratura, independentemente de concurso, aos promotores públicos da Capital com quatro anos de efetivo exercicio na comarca, podendo ser nomeados juizes de primeira, segunda e terceira entrancias. 
Muito recentemente, o decr. n. ${ }^{\circ} 6.253$, de 29 de dezembro de 1933, restringiu êsses dispositivos. Restringiu-os afim de tornar a permissão restrita ás varas criminais. Realmente, substituiu êle o texto do art. 17 do decr. n. 5.179, de 27 de agosto de 1931, modificado pelo decr. n. ${ }^{\circ} 5.215$, de 1 de outubro de 1931, por êste:

"Os promotores públicos com cinco anos de exercicio em promotoria da Capital, ou com exercicio na promotoria durante oito anos, dos quais tres na Capital, poderão ser nomeados para as varas criminais, concorrendo com os juizes de direito".

E atribuiu, como os decretos anteriores, á Primeira Câmara do Tribunal de Justiça a classificação, por merecimento, de dois dos promotores públicos que se inscrevessem, podendo eliminar todos, ou alguns dos candidatos, se julgar que não preenchem êsse requisito, podendo intervir na deliberação o presidente do Tribunal e o procurador geral do Estado.

Resulta, destarte, da confluencia de nomes de juizes de direito e de promotores públicos, nas condições referidas, a organização, pelo Tribunal de Justiça, da lista para a promoção daqueles e para a nomeação dêstes para as varas criminais da Capital e das comarcas de Santos e de Rio Preto. E isso com a dispensa, para os promotores públicos, do concurso, que a Constituição Politica do Estado de São Paulo havia considerado essencial para o primeiro provimento de cargo da magistratura.

Formulou-se, em vista disso, o questionario proposto.

Diante da exposição feita, respondo:

Fioi o art. 55 da Constituição Politica do Estado de São Paulo - que exigia a precedencia de concurso para o primeiro provimento dos cargos de magistratura - derrogado pelo art. 27 do decr. n..$^{\circ} 20.348$, de 29 de agosto de 1931, tornando dispensavel o concurso para as nomeações e promo- 
ções para cargos da magistratura, com exigir para isso apenas a prévia e expressa aprovação do mais alto tribunal judiciario do Estado.

Legítimo é, sem dúvida, o decreto paulista n. 6.253, de 29 de dezembro de 1933, que, restringindo e modificando os dispositivos dos decretos anteriores, n. 5.179 , de 27 de agosto de 1931, e n..$^{\circ} 5.215$, de 1 de outubro de 1931, estabeleceu novas regras para o ingresso dos promotores públicos da Capital de São Paulo na magistratura, autorizando-os a concorrerem com os magistrados de carreira no provimento das varas criminais do Estado, independentemente de concurso. Se desde 1931 podiam êles sèr nomeados juizes de direito das comarcas de primeira, segunda e terceira entrancias, agora somente podem ser nomeados juizes de direito das varas criminais. E nesta, como naquela hipotese, sem concurso, mas em razão do seu tirocinio especializado.

Não disse o decr. $\mathrm{n} .^{\circ} 20.348$, de 29 de agosto de 1931 o chamado Codigo dos Interventores - ser essencial, para nomeações e promoções para os cargos de magistratura, audiencia e aprovação do mais alto tribunal do Estado, por maioria de votos, imputando-se os de todos os seus membros. Não. Exige êle tão somente a sua "prévia" e expressa aprovação" e esta "em escrutinio secreto" Desde que o decreto paulista determina seja organizada a lista, contendo dois dos nomes dos promotores públicos inscritos, pela Primeira Câmara do Tribunal de Justiça, podendo, a demais, intervirem na deliberação o presidente do Tribunal e o procurador geral do Estado, não padece êle do vício de ilegalidade. Ninguem dirá que não sejam do Tribunal de Justiça os acórdãos proferidos por qualquer das suas Camaras. Condiz a medida não somente com o intuito de estabelecer o principio da especialização da justiça criminal, como, ainda, com a organização judiciaria do Estado. Sendo da competencia da Pri- 
meira Camara os julgamentos dos recursos criminais, está ela, mais que as outras, em condições de apreciar, com pleno conhecimento, a valia dos promotores publicos. Poder-se-á, certamente, divergir do criterio do decreto, dispensando aos promotores publicos da Capital do concurso para o seu ingresso na magistratura criminal. Não há, todavia, senão reconhecer estar êle isento da pecha de ilegalidade.

Admitindo, simplesmente para discutir, devesse, na conformidade do disposto no art. 27 do Codigo dos Interventores, ser a prévia e expressa aprovação da lista de nomes. para as nomeações e promoções para cargos de magistratura pelos votos de todos os ministros componentes do Tribunal de Justiça e não apenas pelos votos dos componentes da sua Primeira Camara, acontece que, sendo de 27 de agosto de 1931, o decr. n. ${ }^{\circ}$ 5.179, que a esta tal competencia atribuiu, e de dois dias depois, de 29 de agosto de 1931, o Codigo dos Interventores, que somente em 24 de outubro daquele ano entrou em vigor, ninguem pediu a revisão dele, afim de po-lo em consonancia com o dito Codigo, se dele destoava.

Os atos dos governos estaduais, municipais ou de quaisquer autoridades oriundas da revolução de outubro, anteriores á vigencia daquele decreto e contrários aos preceitos por êle estabelecidos - ficou expresso no art. 32 - poderiam, a requerimento de qualquer interessado direto, ou por iniciativa dos proprios interventores, ou prefeitos, ser revistos e daptados á legislação vigente, modificados ou revogados. $O$ pedido de revisão devia ser formulado dentro do prazo maximo de trinta dias, a contar do início da obrigatoriedade daquele decreto.

Nenhum, que se saiba, foi feito, no sentido de atribuir ao Tribunal de Justiça de São Paulo, em sessão plena de todas as suas Camaras, função que o decr. n. ${ }^{\circ}$ 5.179, de 27 de agosto de 1931, conferira á sua Primeira Camara, e que o decr. n. ${ }^{\circ} 6.253$, de 29 de dezembro de 1933, não modificou. 


\section{III}

Estabelecendo que somente os promotores publicos da Capital possam concorrer com os juizes de direito para o provimento das varas criminais, teve o decreto $\mathrm{n} .{ }^{\circ} 6.253$, de 29 de dezembro de 1933, em vista a circunstância de se dedicarem êles, exclusivamente, ao exercício de seus cargos, circunscrevendo, porisso mesmo, á sua cultura jurídica ao' ramo criminal. Tal não se dá com os promotores publicos das outras comarcas, que podem exercer a advocacia no juizo civel. Ficou isso, de resto, bem explícito na justificação preliminar do decreto, tambem porisso não ferido de ilegalidade. Tão ilegal seria, se o fosse, como o que só a magistrados permite, além dos promotores, inscreverem-se para o provimento das varas criminais.

\section{IV}

Ingressando na magistratura criminal não ficarão os promotores públicos inibidos de se removerem para as varas civeis, por falta de uma lei que isso, expressamente, prö̈ba.

São Paulo, 18 de janeiro de 1934. 